\title{
Komunikasi Tradisi dalam Kepengarangan Hikayat Pelanduk Jenaka
}

\section{Traditional Communication in the Authorship of Hikayat Pelanduk Jenaka}

\author{
ROSLINAABU BAKAR \\ Jabatan Bahasa Melayu, Fakulti Bahasa Moden dan Komunikasi \\ Universiti Putra Malaysia, 43400 Serdang, Selangor, Malaysia \\ lynabubakar@upm.edu.my
}

Published online: 15 April 2017

To cite this article: Abu Bakar, R. 2017. Komunikasi tradisi dalam kepengarangan Hikayat Pelanduk Jenaka. KEMANUSIAAN the Asian Journal of Humanities 24(1): 23-49, https://doi. org/10.21315/kajh2017.24.1.2

To link to this article: https://doi.org/10.21315/kajh2017.24.1.2

\begin{abstract}
Abstrak. Makalah ini memfokus kepada komunikasi tradisi dalam kepengarangan manuskrip Melayu tradisional menerusi Hikayat Pelanduk Jenaka (Cod. Or. 1932). Bagi menggambarkan proses komunikasi tradisi, penulis menggunakan kaedah analisis kandungan serta teknik kualitatif menerusi model R.Lina: Komunikasi Dua Hala Terancang (RL: KDHT) (2013). Analisis kajian ini menunjukkan keunikan komunikasi tradisi dalam kepengarangan manuskrip Melayu tradisional, dan sorotan kepada elemen hubungan pengarang dengan Tuhan, individu, masyarakat dan alam. Makalah ini membahaskan tentang manuskrip Melayu tradisional yang dihasilkan oleh penulisnya yang berupaya menghasilkan mesej sehingga menghiburkan dan membawa maklumat kepada khalayak pembaca.
\end{abstract}

Kata kunci dan frasa: komunikasi tradisi, kepengarangan, manuskrip Melayu tradisional, Hikayat Pelanduk Jenaka

\begin{abstract}
This article discusses the traditional communication in Malay manuscript authorship based on the Hikayat PelandukJenaka (Cod. Or. 1932). The process of traditional communication was analysed using content analysis methods and qualitative research techniques based on the R.Lina model: Two-way Planned Communication (RL: KDHT) (2013). The current analysis demonstrates the uniqueness of traditional communication in the authorship of Malay traditional manuscript in terms of the relationship between its author and God, individuality, society and nature. This article argues that the traditional Malay manuscript is able to generate a message that is entertaining and informative for readers.
\end{abstract}

Keywords and phrases: traditional communication, authorship, traditional Malay manuscript, Hikayat Pelanduk Jenaka

(C) Penerbit Universiti Sains Malaysia, 2017. This work is licensed under the terms of the Creative Commons Attribution (CC BY) (http://creativecommons.org/licenses/by/4.0/). 


\section{Pengenalan}

Yang datang dari orang-orang tua-tua itu dianggap awal, bijaksana dan mungkin lebih dekat kepada bentuk yang asli - dan oleh itu lebih benar, lebih utuh dan tidak dirungkai dari susunan asalnya dan dicemari oleh zaman. (Muhammad Haji Salleh 1997, 183)

Umum mengetahui bahawa masyarakat Melayu mempunyai sejarah budaya yang mantap dan paras tamadun yang tinggi sejak lama dahulu. Sejarah budaya dan paras tamadun yang tinggi tersebut wajar dilestarikan agar kekal sepanjang zaman. Sehubungan itu, pengaplikasian model R.Lina: Komunikasi Dua Hala Terancang (RL: KDHT) menerusi kajian ini amat relevan dan berupaya memperlihatkan komunikasi tradisi dalam kepengarangan manuskrip Melayu tradisional tanpa mengesampingkan aspek budaya dan pandangan dunia masyarakat Melayu. Justeru, fenomena tersebut memperlihatkan gandingan ilmu tradisional dan disiplin ilmu komunikasi yang bersifat sistematik. Proses penyampaian mesej oleh pengarang mengalami proses mendekod, iaitu khalayak pembaca menterjemahkan dan memecahkan simbol-simbol kepada makna. Menurut Roslina (2013b, 59), komunikasi merupakan proses perundingan dan pertukaran makna. Penyampaian maklumat antara peserta komunikasi dapat menghasilkan makna menerusi simbolsimbol.

Kajian mengenai manuskrip Melayu tradisional telah banyak dilakukan oleh para sarjana, penyelidik, orientalis Barat dan tempatan. Kajian-kajian tersebut mencakupi pelbagai disiplin ilmu dan mempunyai kepentingan dalam dunia kesusasteraan Melayu tradisional. Contohnya, Goriaeva (2001) telah mengkaji Hikayat Marakarma yang tersimpan di Saint Petersburg. Beliau telah menganalisis kisah Hikayat Marakarma mengikut algoritma Propp. Berdasarkan kajiannya, beliau merumuskan bahawa struktur kepengarangan hikayat Melayu mempunyai gaya stereotaip. Merujuk kepada dapatan kajian tersebut, penulis berpendapat pandangan mengenai gaya kepengarangan manuskrip Melayu tradisional sewajarnya dilihat secara tuntas dan tidak seharusnya dianggap stereotaip. Setiap naskhah yang dihasilkan oleh pengarang Melayu tradisional memperlihatkan daya intelektual, penyampaian pelbagai idea yang bersifat unik dan merangkumi adat istiadat, budaya dan pelbagai persoalan yang berhubung dengan kehidupan masyarakat Melayu khususnya. Berdasarkan pendapat Ding Choo Ming (2009, 146), lahirnya manuskrip Nusantara dengan isinya yang pelbagai, kait mengait antara satu dengan yang lain adalah antara ciri kepengarangan manuskrip di Nusantara. 
Kajian mengenai manuskrip Melayu tradisional turut giat dilakukan oleh para sarjana tempatan. Antaranya, kajian mengenai pengarang serta kepengarangan Melayu oleh Muhammad Haji Salleh (1997) dan kajian mengenai langkahlangkah memasyarakatkan manuskrip Melayu oleh Abu Hassan Sham (1997). Selain itu, Siti Hawa Salleh (1987; 1997), Harun Mat Piah (1994), Haron Daud (2004), Liaw Yock Fang (1975) dan Ding Choo Ming (1997; 2003; 2009) turut produktif menghasilkan pelbagai aspek kajian mengenai manuskrip Melayu tradisional. Sebagai contoh, Ding Choo Ming (2003) turut menghasilkan kajian mengenai kepentingan manuskrip Melayu, menulis kritikan dan kupasan terhadap kajian mengenai manuskrip Melayu tradisional yang pernah dilakukan oleh para sarjana, orientalis Barat dan tempatan. Jelas bahawa, usaha para pengkaji tempatan dan orientalis Barat amat membantu memperkayakan kajian mengenai manuskrip Melayu tradisional. Namun demikian, menurut Ding Choo Ming (2003, 152), sehingga kini masih belum terdapat teori sastera yang sesuai untuk mengkaji sastera Melayu tradisional walaupun terdapat para pengkaji seperti Muhammad Haji Salleh telah cuba melakukannya. Menurutnya, adalah tidak wajar kajian mengenai teks-teks manuskrip sebagai sumber sastera Melayu tradisional terusmenerus dikaji berdasarkan teori sastera yang diimport dari negara-negara Barat. Justeru, bertitik tolak daripada pendapat Ding Choo Ming (2013) itu, penulis berpendapat bahawa telah tiba ketikanya kajian mengenai manuskrip Melayu tradisional digandingkan dengan teori atau model tempatan yang bersifat sistematik di samping berupaya menyerlahkan budaya dan pandangan dunia Melayu. Sebagai contoh, pengaplikasian model RL: KDHT (2013) dalam kajian ini berupaya memperlihatkan pengisian ruang kosong kajian terdahulu. Hal ini demikian kerana model RL: KDHT yang asalnya dibina oleh Roslina Abu Bakar (2011) menerusi tesis doktor falsafahnya berupaya membuktikan keselarian antara ilmu komunikasi yang bersifat sistematik, pandangan dunia Melayu dan sastera Melayu tradisional.

Roslina (2012; 2013a) turut menghasilkan kertas kerja yang menjelaskan secara terperinci model RL: KDHT untuk merungkai keunikan cerita rakyat Melayu dan tradisi lisan. Dalam pada itu, beliau telah berupaya membuktikan kesepadanan antara genre sastera tradisional dengan teori yang bersifat sistematik. Selain itu, Roslina (2013b) turut memperincikan elemen model RL: KDHT untuk menganalisis cerita-cerita rakyat Melayu. Di samping itu, kajiannya turut diperluaskan mengenai unsur komunikasi seperti unsur asas, unsur tambahan, elemen budaya dan pandangan dunia Melayu. Sementara itu, Nurhayati Diyana (2015) turut mengaplikasikan model komunikasi RL: KDHT untuk menganalisis konflik dalam drama Shaharom Husain. Kajiannya berupaya mengenal pasti aspek konflik kekuasaan, konflik kemasyarakatan dan konflik status atau kedudukan menerusi kumpulan drama Shaharom Husain. 
Secara total, setelah merujuk kepada data perolehan daripada kajian terdahulu, penulis menjustifikasikan bahawa ilmu komunikasi mempunyai kepentingan dalam penyampaian mesej oleh sumber kepada penerima dalam genre tradisional, moden, lisan dan bertulis. Justeru, kajian ini turut membuktikan bahawa model RL: KDHT yang sistematik sifatnya amat relevan digandingkan dengan kepengarangan manuskrip Melayu tradisional untuk memperlihatkan keunikan komunikasi tradisi. Keistimewaan kajian ini diperlihatkan menerusi adunan dua disiplin ilmu yang berbeza namun saling melengkapi. Model komunikasi tersebut berupaya menggambarkan gaya kepengarangan manuskrip Melayu tradisional secara terperinci malah memperlihatkan proses penyaluran mesej daripada sumber kepada penerima tanpa mengesampingkan pandangan alam dan ruang lingkup budaya Melayu. Justifikasi tersebut diperkukuhkan menerusi pendapat Mansor, Ramli dan Shawaluddin $(1984,5)$ yang menyatakan bahawa ilmu komunikasi adalah penting dan perlu sebagai ilmu bantu bagi mana-mana bidang yang mengkaji sifat-sifat kemasyarakatan manusia. Komunikasi bukan sahaja satu bidang yang boleh dikaji secara tersendiri, tetapi juga boleh digunakan untuk membantu kita mempelajari dan memahami bidang-bidang ilmu lain.

Dengan keadaan demikian, kerelevanan model komunikasi RL: KDHT dan kajian ini berupaya membantu keberhasilan pencapaian objektif kajian. Kajian ini mempunyai dua objektif. Pertama, untuk memperlihatkan komunikasi tradisi dalam kepengarangan manuskrip Melayu tradisional, iaitu Hikayat Pelanduk Jenaka (Cod. Or. 1932). Kedua, untuk menganalisis Hikayat Pelanduk Jenaka berlandaskan model RL: KDHT. Komunikasi tradisi dalam kepengarangan manuskrip Melayu tradisional memperlihatkan kemahiran pengarang untuk mengarang hasil tulisan atau karangan yang berupaya menyalurkan mesej dan membawa kesan kepada penerima atau khalayak pembaca secara bersama. Hal ini kerana model RL: KDHT berupaya menggambarkan proses komunikasi yang terancang untuk merealisasikan aspek hubungan dan kandungan ke arah pencapaian matlamat komunikasi tradisi yang dilaksanakan. Sehubungan itu, untuk mencapai kejayaan matlamat tersebut, komunikasi tradisi dalam kepengarangan Hikayat Pelanduk Jenaka turut dirungkai dengan menghubungkan elemen pengarang dengan Tuhan, individu, masyarakat dan alam. Akhirnya, proses komunikasi tradisi dalam kepengarangan Hikayat Pelanduk Jenaka berupaya membawa perubahan sikap, memujuk dan mempengaruhi seseorang (khalayak pembaca). Oleh itu, penggabungjalinan kepengarangan Hikayat Pelanduk Jenaka dengan model RL: KDHT berupaya menjelaskan hubungan ilmu komunikasi dan kerelevanannya dengan disiplin sastera dan budaya.

Daripada sudut lain, tamadun zaman lampau yang terkandung dalam manuskrip Melayu tradisional mempunyai unsur pelajaran yang memberi panduan bertingkah 
laku. Lantaran itu, makna tersurat dan tersirat menerusi mesej yang disalurkan oleh pengarang kepada khalayak pembaca perlu disebarkan dengan seluas-luasnya sebagai usaha pengekalan jati diri bangsa Melayu. Secara tuntas, kepengarangan manuskrip Melayu tradisional yang diperlihatkan menerusi aspek komunikasi tradisi berupaya memperjelaskan proses pemindahan maklumat daripada pengarang kepada khalayak pembaca secara terancang, sekali gus membawa pelbagai manfaat kepada peserta komunikasi (sumber dan penerima).

\section{Hikayat Pelanduk Jenaka}

Manuskrip Hikayat Pelanduk Jenaka (Cod. Or. 1932) berukuran $175 \times 125 \mathrm{~cm}$, mempunyai 159 patah perkataan dan 13 baris dalam setiap muka surat. Manuskrip ini ditulis menggunakan dakwat hitam di atas kertas bersifat tera air. Hikayat Pelanduk Jenaka ditulis oleh Abdul Hakim yang merupakan seorang jurutulis Melayu di Pejabat Sekretari. Mengikut catatan di manuskrip tersebut, Hikayat Pelanduk Jenaka pernah dipunyai oleh Encik Van der Capellen. Beliau telah membelinya di lelongan Milles yang diadakan pada 7 hingga 14 Mei 1870.

Manuskrip Melayu ini mengisahkan kehidupan masyarakat seisi rimba yang amat taat kepada Pelanduk Jenaka yang menggelarkan dirinya sebagai Syeikh Alam di Rimba (SAdR). SAdR amat masyhur namanya dalam kalangan segala isi rimba dengan tipu dayanya. Tipu daya oleh Pelanduk Jenaka ini menggambarkan perwatakannya yang pintar dan bijak dalam menangani pelbagai masalah dan penyelesaian konflik yang dihadapi oleh seisi rimba. Interaksi antara watak binatang yang digambarkan menerusi Hikayat Pelanduk Jenaka berupaya menghiburkan, terkandung pelbagai unsur pelajaran yang berupaya membangunkan jasmani, emosi, intelek dan sahsiah golongan pembaca.

\section{Pengarang Melayu}

Menerusi kajian ini, pengarang atau penyalin manuskrip Melayu tradisional dianggap sebagai sumber yang bertindak sebagai pengarang dan penyampai mesej kepada penerima atau khalayak pembaca. Menerusi model RL: KDHT, sumber yang bertindak sebagai pengarang merupakan unsur asas yang menyampaikan mesej kepada penerima. Menurut Roslina (2013b, 105), sumber yang merupakan punca mesej perlu memainkan peranan penting dalam proses komunikasi. Sebagai contoh, sumber yang bertindak sebagai punca komunikasi perlu kritis dan mempunyai pengetahuan mengenai mesej yang mahu disalurkan supaya mesej tersebut berupaya membawa sesuatu makna kepada penerima. Menurut Muhammad Haji Salleh $(1997,190)$, pengarang merupakan istilah yang terdekat untuk maksud yang kita inginkan, dan kata ini tiada berkecenderungan untuk sastera lisan atau 
tulisan, malah mencakupi kedua-duanya. Yang lebih dipentingkan oleh istilah ini ialah perbuatan mengarang itu sendiri. Oleh itu, ciri-ciri sumber atau pengarang akan menentukan kejayaan proses komunikasinya. Menurut Roslina (2013b, 85), antara faktor yang menyumbang kepada keberkesanan proses komunikasi dua hala ialah taraf pengetahuan individu. Sumber perlu peka kepada taraf pengetahuan khalayak agar proses penciptaan dapat diapresiasi dengan sempurna. Menurut Mansor, Ramli dan Shawaluddin (1984, 32), sesuatu komunikasi itu mendatangkan kesan sekiranya punca atau penerima mempunyai empat ciri, iaitu kemahiran berkomunikasi, sikap, taraf pengetahuan dan kedudukan dalam sesuatu sistem sosiobudaya.

Perbuatan mengarang oleh pengarang yang kompeten tentunya memerlukan perancangan yang teliti. Pertama, pengarang terlebih dahulu mengenkod mesej yang mahu disampaikan kepada khalayak pembaca dalam fikirannya. Seterusnya, pembaca pula perlu mendekod, iaitu memecahkan simbol-simbol perkataan yang ditulis oleh pengarang. Sekiranya mesej yang disampaikan oleh pengarang mempunyai kesepadanan dan lapangan rujuk yang sama dengan khalayak pembaca, maka proses komunikasi yang dilaksanakan akan tercapai matlamatnya. Dalam hal ini, mesej atau perutusan merupakan elemen penting dalam proses komunikasi dan membawa tujuan yang ingin disampaikan oleh pengarang kepada khalayak pembaca.

Menerusi proses komunikasi, model RL: KDHT berupaya memperlihatkan kondisi, tanggungjawab dan kreativiti pengarang Melayu tradisional untuk menyampaikan mesej yang bermakna dan membawa kesan dalam kalangan pembaca. Peranan pengarang Melayu tradisional yang pakar dalam bidangnya itu turut dinyatakan oleh Hashim $(1994,328)$ yang berpendapat bahawa masyarakat Melayu mempunyai daya cipta atau daya kreatif yang tinggi. Kekreatifan masyarakat Melayu terlihat bukan sahaja dalam bidang kerja tangan atau kraftangan, tetapi juga dalam hal penyaluran fikiran.

Menerusi proses komunikasi tradisi, kreativiti penyaluran fikiran oleh sumber atau pengarang Melayu tradisional akan menentukan keberkesanan mesej yang disalurkan kepada penerima. Menurut Roslina (2013b, 85), sumber perlu mengaplikasikan pengetahuan, pengalaman, kemahiran, kreativiti dan kecerdasan. Ciri-ciri tersebut perlu disesuaikan dengan tahap pengetahuan penerima atau khalayak kerana penyesuaian yang dilakukan berupaya membantu mempermudahkan khalayak mendekod mesej yang disalurkan oleh sumber. Kenyataan tersebut bersesuaian dengan proses penciptaan Hikayat Pelanduk Jenaka yang melibatkan penggabungjalinan elemen intrapersonal seperti pengetahuan, 
pengalaman, kemahiran, kreativiti dan kecerdasan. Hal ini memperjelaskan peranan pengarang yang perlu mempunyai pengetahuan mengenai apa yang mahu dikarangnya, perlu mementingkan elemen intrapersonal, mempunyai kreativiti dan bakat semula jadi seperti kecerdasan berbahasa. Di samping itu, mereka perlu menghubungkan diri dengan unsur naturalis serta pelbagai bakat semula jadi yang dimiliki untuk meningkatkan tahap kepengarangannya. Segalanya dilakukan agar idea mesej yang mahu ditintakan berupaya didekod, diapresiasi dengan sempurna lalu mendatangkan makna kepada khalayak penerima.

Model RL: KDHT mempunyai ciri-ciri dan elemen-elemen yang saling melengkapi untuk merungkai proses komunikasi yang dilaksanakan. Sebagai contoh, elemen kecerdasan pelbagai dalam binaan model RL: KDHT bersifat saling hubung dengan proses komunikasi. Kecerdasan bahasa/linguistik, kecerdasan interpersonal, kecerdasan intrapersonal dan kecerdasan naturalis berupaya membantu keberkesanan proses komunikasi. Antaranya adalah seperti kecerdasan intrapersonal dan kecerdasan linguistik yang dimiliki oleh sumber berupaya menghibur, menyempurnakan rohani dan memberi manfaat kepada peserta komunikasi. Begitu juga dengan kecerdasan bahasa/linguistik turut membantu pembentukan intelek para peserta komunikasi. Kecerdasan naturalis pula berupaya membawa kesan emosi peserta komunikasi.

Kemahiran dan bakat yang dipunyai oleh pengarang turut dinyatakan oleh Ding Choo Ming $(1997,221)$ yang menyatakan bahawa dalam kesusasteraan Melayu tradisional, nama pengarang meliputi semua orang yang terlibat dalam mengarang. Seperti seniman lain, pengarang dewasa amat versatil, penuh dengan daya kreativiti dan imaginasi. Selain mempunyai tabung ilmu pengetahuan yang luas, mereka mempunyai sifat semula jadi seperti pandai bercerita dengan bahasa yang indah. Sesungguhnya pengarang yang pandai bercerita dengan bahasa yang indah itu berupaya menyampaikan sesuatu makna serta kesan pelajaran dan hiburan kepada khalayak pembaca. Kenyataan tersebut turut diperlihatkan menerusi komunikasi tradisi dalam kepengarangan Hikayat Pelanduk Jenaka. Pengarang Hikayat Pelanduk Jenaka turut kreatif menyisipkan unsur lucu menerusi watak dan perwatakan pelbagai binatang di rimba di samping menyalurkan pelbagai mesej yang berupaya membawa sesuatu makna kepada khalayak pembaca. Sebagai contoh, mesej yang membawa makna seperti 'jangan berseteru' disalurkan kepada khalayak pembaca sebagai panduan dan teladan seperti dalam petikan berikut:

Maka kata pelanduk "hai sekelian tuan-tuan pada hari inilah engkau aku perdamaikan dengan sekawan harimau itu jangan engkau berseteru dengan harimau itu..." (Cod. Or. 1932, 12) 
Petikan tersebut menggambarkan daya kreativiti dan imaginasi pengarang bercerita dengan bahasa yang indah untuk menggambarkan peristiwa perdamaian antara binatang buas dengan binatang yang lemah sifatnya. SAdR telah dipersonifikasikan dan diperanankan selaku pemimpin yang bertanggungjawab, memperlihatkan mesej mendidik individu dan masyarakat agar hidup harmoni serta mengamalkan amalan berbaik-baik sesama manusia. Mesej tersebut berupaya membawa isi yang bermakna setelah didekod oleh khalayak pembaca lalu dijadikan pelajaran dan teladan dalam kehidupan nyata.

Di sebalik itu, petikan tersebut (Cod. Or. 1932, 12) turut memperlihatkan elemen kandungan menerusi mesej yang disalurkan oleh pengarang. Fenomena tersebut bersesuaian dengan komunikasi itu sendiri yang menekankan aspek kandungan dan hubungan. Aspek kandungan merujuk kepada harapan pengarang terhadap tindak balas dan tingkah laku khalayak pembaca setelah mentafsir mesej yang disalurkan. Mesej yang mempunyai makna berupaya dijadikan iktibar dan pengajaran kepada khalayak pembaca sebagai panduan dalam kehidupan nyata. Oleh itu, kejayaaan mesej yang disalurkan oleh sumber atau pengarang bergantung kepada kejayaan hubungan (bagaimana komunikasi itu berlaku antara sumber dengan khalayak).

Di samping itu, intrapersonal pengarang dan hubungannya dengan Tuhan serta prinsip komunikasi Islam yang dilaksanakan berupaya membantu kejayaan proses komunikasi. Sebagai contoh, komunikasi tradisi dalam kepengarangan manuskrip Melayu tradisional turut membantu dalam membawa kesan kerohanian dan pembentukan sahsiah peserta komunikasi Muslim dan bukan Muslim.

\section{Metodologi Kajian dan Kerangka Teori}

Penganalisisan kajian mengenai manuskrip Melayu tradisional Hikayat Pelanduk Jenaka ini dilakukan dengan memanfaatkan pendekatan analisis deskriptif berlandaskan model RL: KDHT (2013). Model RL: KDHT merupakan model komunikasi dua hala terancang yang dibina oleh Roslina Abu Bakar menerusi kajiannya mengenai penyampaian cerita rakyat Melayu oleh penglipur lara. Walaupun pada asasnya model tersebut direka cipta berlandaskan situasi komunikasi interpersonal, namun terdapat beberapa elemen di dalamnya yang amat bersesuaian untuk merungkai proses kepengarangan manuskrip Melayu tradisional. Hal ini demikian kerana model komunikasi tersebut amat erat kaitannya dengan ruang lingkup budaya dan pandangan alam Melayu. Oleh itu, kajian ini berupaya memperlihatkan kekuatan kepengarangan Hikayat Pelanduk Jenaka yang saling kait dengan aspek nilai, peraturan, budaya dan amalan kehidupan masyarakat Melayu. Dalam konteks ini, aspek-aspek tersebut diperlihatkan menerusi elemen 
pengarang dan hubungannya dengan Tuhan, individu, masyarakat dan alam. Hal ini secara tidak langsung membuktikan bahawa model RL: KDHT ini merupakan wahana yang berupaya memperlihatkan proses komunikasi dan hubungannya dengan aspek budaya serta pandangan dunia, kepercayaan, pegangan, pemikiran, falsafah dan keseluruhan cara hidup masyarakat Melayu menerusi Hikayat Pelanduk Jenaka. Merujuk kepada kenyataan Roslina (2013b, 94), komunikasi turut berfungsi sebagai penyebaran hasil kebudayaan dan melestarikan warisan masa lalu dalam kalangan generasi kini.

Selain itu, budaya amat berperanan ke arah keberkesanan proses komunikasi. Sebagai contoh, pentafsiran mesej akan menjadi sukar dan matlamat komunikasi tidak akan tercapai sekiranya sumber dan penerima terdiri daripada latar budaya yang berbeza. Oleh itu, aspek pandangan dunia dan budaya Melayu yang terangkum di dalam Hikayat Pelanduk Jenaka amat bersesuaian dirungkai menerusi model RL: KDHT yang tidak mengesampingkan pandangan dunia dan alam Melayu. Hal ini kerana model komunikasi RL: KDHT turut mementingkan kesepadanan taraf pengetahuan serta kedudukan sumber dan penerima dalam sesuatu sistem sosiobudaya supaya isi mesej yang pelbagai makna berupaya diterjemahkan dengan berkesan. Justeru, kajian ini berupaya menyerlahkan kehebatan kepengarangan manuskrip Melayu tradisional yang menjelaskan hubungan komunikasi tradisi dan ilmu sastera itu sendiri.

\section{Kerangka Teori Model R.Lina: Komunikasi Dua Hala Terancang (RL: KDHT)}

Model RL: KDHT (2013) dibina untuk menggambarkan komunikasi dua hala yang terancang antara sumber dengan penerima. Binaannya menggambarkan komunikasi tidak wujud secara terpencil kerana proses komunikasi saling berhubung dengan setiap aspek lain dalam kehidupan. Ciri-ciri model RL: KDHT adalah seperti berikut:

1. Proses komunikasi berbentuk bulatan dan secara transaksional, secara bersama-sama dan tindak balas berlaku antara sumber dengan penerima ketika proses komunikasi dua hala.

2. Unsur asas dan tambahan merupakan penggerak kepada proses komunikasi dua hala antara sumber dengan penerima. Terdapat unsur asas (empat unsur) dan unsur tambahan (dua unsur) yang merupakan penggerak proses komunikasi antara sumber dengan penerima. Perincian unsur asas dan unsur tambahan menerusi model RL: KDHT adalah seperti berikut: 
(i) Unsur asas

a. Sumber: Menerusi model RL: KDHT, sumber bertindak sebagai penyampai mesej kepada penerima. Sumber yang kompeten mempunyai gabung jalin elemen intrapersonal seperti pengetahuan, pengalaman, kemahiran, kreativiti dan kecerdasan.

b. Mesej: Mesej merupakan perutusan yang ingin disampaikan oleh sumber. Mesej atau perutusan merupakan elemen penting dan membawa tujuan yang ingin disampaikan oleh sumber kepada khalayak. Sumber menjalani proses enkod sebelum menyampaikan perutusan kepada khalayak pembaca. Proses enkod merupakan penghasilan simbol-simbol dan pengeluaran maklumat oleh pengirim kepada penerima. Penerima yang menerima mesej yang disalurkan oleh sumber akan mengalami proses mendekod, iaitu memecahkan simbol-simbol tersebut kepada makna yang difahami. Justeru, kemahiran berkomunikasi, sikap, taraf pengetahuan dan kedudukan dalam sistem sosiobudaya perlu dipentingkan agar mesej yang disalurkan oleh sumber kepada penerima akan membawa kepada sesuatu makna.

c. Saluran: Menerusi model RL: KDHT, saluran merupakan alat atau medium yang membawa mesej. Pemilihan saluran oleh sumber merupakan faktor penting untuk menentukan keberkesanan proses komunikasi.

d. Penerima/Khalayak: Khalayak merupakan penerima, iaitu para penonton komunikasi interpersonal. Penerima membawa erti seseorang yang memerhati dan merujuk kepada sesiapa sahaja yang menerima, mendengar, membaca dan melihat sesuatu komunikasi walaupun penerima komunikasi tersebut hanya terdiri daripada seorang individu sahaja. Model RL: KDHT menjelaskan bahawa komunikasi dua hala yang terancang akan menyebabkan sumber dan penerima/khalayak menggunakan informasi bersama sehingga berjaya memahami apa yang dimaksudkan antara satu sama lain. 
(ii) Unsur tambahan

a. Tindak balas: Tindak balas merupakan elemen yang menghasilkan sebarang reaksi atau respons dalam kalangan penerima. Sebarang rangsangan dan tindak balas terhadap komunikasi itu akan menentukan perjalanan komunikasi seterusnya dan proses ini berlaku secara bulatan dalam bentuk transaksional.

b. Gangguan: Gangguan berlaku dalam proses komunikasi ketika sumber sedang mengirim mesejnya kepada khalayak. Gangguan turut berlaku dalam saluran atau semasa penerima menerima mesej yang dikirimkan. Apa sahaja yang mengganggu kelicinan proses komunikasi diistilahkan sebagai gangguan.

3. Menerusi model RL: KDHT, komunikasi berlaku dalam pelbagai tahap dan tiga daripada tahap-tahap tersebut ialah intraperibadi, antara peribadi dan individu dengan kumpulan. Tahap-tahap tersebut digambarkan menerusi elemen dalaman model RL: KDHT yang amat erat hubungannya dengan alam dan budaya Melayu, iaitu hubungan pengarang Melayu dengan Tuhan, individu, masyarakat dan alam. Perincian elemen tersebut dijelaskan seperti berikut:

(i) Hubungan sumber dengan Tuhan: Menurut model RL: KDHT, insan yang seimbang daripada segi intelek, rohani, emosi dan jasmani amat berhubungan dengan kepercayaan dan kepatuhan kepada Tuhan. Sehubungan itu, untuk mencapai keberkesanan proses komunikasi, komunikasi berlandaskan Islam perlu dipraktikkan. Sumber menyampaikan mesej mengikut kadar keupayaannya dan tanggungjawab tersebut turut memperlihatkan tugas komunikasi sebagai satu tugas yang penting dalam perspektif Islam.

Menerusi model RL: KDHT lagi, hubungan antara sumber dengan Tuhan mencakupi elemen intrapersonal serta menitikberatkan komunikasi daripada sudut Islam yang berlandaskan prinsip, etika, norma, adat dan budaya masyarakat Melayu yang beragama Islam. Justeru, hubungan sumber dengan Tuhan menggambarkan kepentingan penyampaian mesej dengan berkesan berlandaskan 
perspektif Islam dan berpandu kepada perintah-perintah yang terdapat dalam al-Quran dan hadis. Keindahan dan sifat-sifat murni Rasulullah SAW daripada segi akhlak, adab berkomunikasi dan pengajaran yang terkandung dalam al-Quran turut dititikberatkan ke arah membantu keberkesanan proses komunikasi dua hala. ${ }^{1}$

(ii) Hubungan sumber dengan individu: Hubungan sumber dengan individu menerusi model RL: KDHT melengkapkan proses komunikasi yang dilaksanakan kerana komunikasi melibatkan dimensi kandungan (merujuk kepada tindak balas tingkah laku peserta komunikasi yang diharapkan) dan hubungan (bagaimana komunikasi berlaku antara sumber dengan penerima).

(iii) Hubungan penglipur lara dengan masyarakat: Hubungan penglipur lara dengan masyarakat memaparkan fungsi mesej yang disalurkan kepada masyarakat sebagai komunikasi sosial dan kawalan sosial, kesedaran terhadap nilai dan etika dalam kehidupan bermasyarakat.

(iv) Hubungan sumber dengan alam: Pandangan dunia dan fenomena alam yang diolah oleh sumber menerusi mesej yang disalurkan kepada penerima berupaya membawa kesan keindahan, fantasi, kerohanian (ketuhanan) dan kognitif. [Untuk penjelasan lanjut mengenai kerangka teori model RL: KDHT, lihat Roslina (2013b, 83-99).]

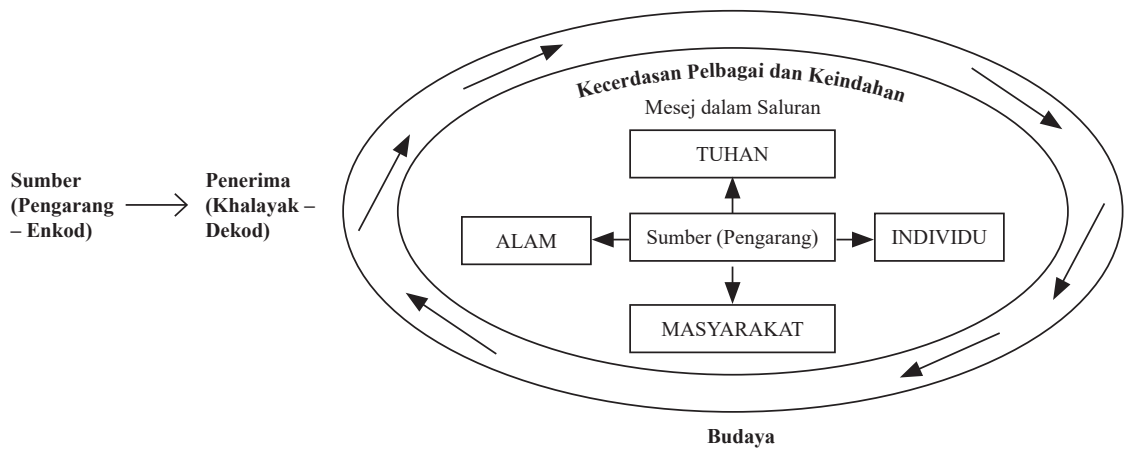

Rajah 1. Kerangka model RL: KDHT

Sumber: Dipetik dan diubah suai daripada Roslina (2013b, 98) 


\section{Dapatan Kajian dan Perbincangan}

Model RL: KDHT direka cipta berlandaskan situasi komunikasi interpersonal, namun terdapat beberapa elemen atau ciri model tersebut yang bersesuaian digandingkan dengan komunikasi tradisi kepengarangan manuskrip Melayu tradisional. MenurutRoslina (2013b, 87), binaan model RL: KDHTmenggambarkan proses komunikasi yang tidak wujud secara terpencil kerana proses komunikasi saling berhubung dengan setiap aspek dalam kehidupan. Selain mengguna pakai unsur asas dan tambahan, binaan elemen seperti hubungan penglipur lara dengan Tuhan, individu, masyarakat dan alam menerusi model tersebut amat relevan dengan ruang lingkup dunia Melayu. Kenyataan tersebut bersesuaian dengan pendapat Siti Hawa $(1987,46)$ yang menyatakan sebuah manuskrip ialah saksi dokumentatif bahasa, peristiwa, tempat dan zaman ia dilahirkan. Melalui genrenya, ia memaparkan konsep kebudayaan atau kehidupan masyarakatnya.

Selain itu, penghasilan sesebuah manuskrip bergantung kepada kemahiran dan tanggungjawab pengarangnya. Kenyataan tersebut sebagaimana pendapat Muhammad Haji Salleh (1997, 208-209):

Pengarang sebagai pawang, dalang, penghulu, penglipur lara dan bidan menduduki puncak kuasa dan pengaruh dalam masyarakatnya. Pengarang muncul daripada sekumpulan manusia yang lebih terpelajar dan bijaksana, berkuasa dan berpengaruh. Di puncak susunan masyarakat itu dia harus menanggung beban untuk menyampaikan ilmu yang ada padanya kepada ahli-ahli masyarakatnya yang terpelajar, yang buta huruf dan umumnya tidak senasib baik sepertinya.

Sehubungan itu, untuk menyalurkan mesej yang membawa pelbagai makna dalam kehidupan masyarakat, proses kepengarangan amat memerlukan perancangan yang teliti. Justeru, makalah ini memperlihatkan aplikasi model RL: KDHT yang menggambarkan proses enkod, iaitu proses penghasilan simbol-simbol dan pengeluaran maklumat oleh pengirim kepada penerima. Selain itu, turut diperlihatkan ialah proses dekod, iaitu penerima menterjemahkan dan memecahkan simbol-simbol tersebut kepada makna. Sesungguhnya, proses komunikasi tersebut perlu dilalui oleh pengarang dan khalayak pembaca ke arah pencapaian matlamat komunikasi. Sumber yang mempunyai perancangan teliti akan menghasilkan penulisan yang jelas dan menyalurkan isi mesej yang berupaya dikongsi secara bersama. Menurut Roslina (2013b, 115), untuk menghasilkan komunikasi dua hala yang berkesan, mesej yang dienkodkan oleh sumber perlu mempunyai isi, iaitu maklumat. Isi komunikasi merupakan perutusan dan elemen penting dalam proses komunikasi serta disalurkan menerusi suatu medium atau saluran. 
Selain itu, makalah ini berupaya memperlihatkan keintelektualan pengarang Hikayat Pelanduk Jenaka yang menghasilkan matlamat menghibur di samping memberi pelajaran ke arah membentuk nilai budi, norma berperlakuan dan bertingkah laku dalam khalayak pembaca. Pengarang dan khalayak pembaca yang terdiri daripada lapang rujuk yang sama berupaya menghasilkan kejayaan elemen hubungan dan kandungan. Elemen hubungan merujuk kepada bagaimana komunikasi itu berlaku manakala elemen kandungan pula merujuk kepada tindak balas tingkah laku khalayak pembaca yang diharapkan oleh pengarang. Dalam konteks ini, mesej disalurkan oleh pengarang kepada khalayak pembaca menerusi simbol-simbol yang difahami bersama, lalu menimbulkan makna. Pelbagai penggunaan gaya bahasa seperti sinisma, metafora, asosiasi, simbolik, alegori dan antonomasia dibawakan oleh pengarang Hikayat Pelanduk Jenaka menerusi simbol-simbol perkataan. Simbol-simbol perkataan tersebut kemudiannya dipecahkan atau diterjemahkan oleh penerima kepada makna menerusi proses dekod. Proses pemahaman simbol mempunyai lima peringkat, iaitu (1) penerimaan dengan cara pembaca menanggap dengan pancaindera, (2) perbandingan, iaitu membandingkan simbol-simbol yang diterima dengan simbol yang sedia diketahui oleh pembaca, (3) pengakuan ke atas penerimaan sekiranya terdapat persamaan antara simbol yang baharu diterima dengan simbol-simbol yang pernah dialami, (4) pentafsiran sekiranya simbol yang ditanggap berada dalam lapang rujuk yang sama. Sekiranya simbol-simbol yang ditanggap berada dalam lapang rujuk yang sama, pentafsiran akan berjaya dilakukan ke arah proses terakhir, iaitu (5) pemahaman yang merupakan penentuan kejayaan proses komunikasi tradisi tersebut.

Menerusi kepengarangan Hikayat Pelanduk Jenaka, diperlihatkan pelbagai peristiwa kebijaksanaan SAdR menyelesaikan pelbagai masalah yang dihadapi oleh seisi rimba dan lautan. Fenomena tersebut memaparkan elemen bekerjasama, bertanggungjawab, sikap masyarakat binatang yang kuat membantu yang lemah, saling sayang-menyayangi, saling hormat-menghormati, faham-memahami antara satu sama lain serta memupuk semangat perpaduan demi keharmonian rimba dan lautan. Persoalan tersebut disalurkan kepada penerima (khalayak pembaca) secara tersurat dan tersirat. Penyampaian oleh sumber menggambarkan kehalusan budi bahasa, tertib peraturan dan ketinggian nilai budi merujuk kepada nilai Melayu. Perihal ini dirungkaikan berdasarkan hubungan antara pengarang dengan Tuhan, individu, masyarakat dan alam.

\section{Pengarang Melayu dan Hubungannya dengan Tuhan, Individu, Masyarakat dan Alam}

Binaan model RL: KDHT pada asasnya tertumpu kepada komunikasi dua hala terancang dalam penyampaian cerita rakyat Melayu oleh penglipur lara kepada 
khalayak. Proses komunikasi dua hala terancang yang dihasilkan oleh komunikasi lisan dan bukan lisan oleh penglipur lara berupaya menggambarkan nilai dan budaya tradisi masyarakat Melayu yang bersifat unik. Segalanya diperlihatkan menerusi proses komunikasi dan hubungan sumber dengan Tuhan, alam dan sesama manusia (Roslina 2013b, 83-99).

Selain itu, merujuk kepada kenyataan Harun Mat Piah (1994, 252-253), persoalan pengarang dan kepengarangan dalam kesusasteraan Melayu klasik amat sedikit dibicarakan, berbanding pembicaraan dalam aspek-aspek yang lain seperti teks, genre, pensejarahan malah pemikiran pengarang. Bertitik tolak daripada pendapat tersebut, kajian ini dilaksanakan untuk merungkai persoalan pengarang dan kepengarangan dalam kesusasteraan Melayu tradisional serta hubungannya dengan disiplin ilmu komunikasi. Justeru, pengaplikasian model RL: KDHT menerusi makalah ini berupaya memperjelaskan proses komunikasi tradisi pada tahap intraperibadi, antara peribadi dan individu dengan kumpulan. Fenomena tersebut diperlihatkan menerusi hubungan sumber dengan Tuhan, individu, masyarakat dan alam. Penggabungan tiga tahap tersebut melengkapkan proses kepengarangan sehingga berupaya membawa isi mesej yang bermakna dalam kalangan khalayak. Kenyataan tersebut sebagaimana menurut Shahnon Ahmad (1994, 5), "dalam cereka umpamanya, pengarang akan memperluaskan komunikasi para wataknya dalam kewujudan dua dimensi dan watak-watak dalam dua dimensi itu pula perlu sedar tentang adanya tiga entiti yang saling berinteraksi, iaitu dirinya, alamnya dan Tuhannya".

\section{Pengarang dan Hubungannya dengan Tuhan}

Agama merupakan sebahagian daripada aspek kehidupan, manakala Islam melahirkan budaya dan diperkembangkan menerusi proses komunikasi. Allah SWT menuntut umat-Nya agar berpesan-pesan antara satu sama lain. Sebagai analoginya, sumber dan hubungannya dengan Tuhan menerusi model RL: KDHT berupaya menyerlahkan komunikasi daripada sudut Islam, berlandaskan prinsip, etika, norma, adat dan budaya masyarakat Melayu yang beragama Islam. Menurut Roslina (2013b, 88), hubungan sumber dengan Tuhan menerusi model RL: KDHT memperlihatkan kepentingan tugas komunikasi menerusi perspektif Islam, merangkumi tanggungjawab serta tindakan sumber dalam menyampaikan pesan atau mesej yang berpandu kepada prinsip-prinsip komunikasi tertentu yang digariskan oleh al-Quran dan as-Sunnah.

Sebagai contoh, mesej yang disalurkan oleh sumber kepada penerima menerusi komunikasi tradisi dalam kepengarangan Hikayat Pelanduk Jenaka menitikberatkan unsur kebenaran. Unsur kebenaran tersebut berfungsi sebagai 
pedoman serta panduan dalam bertingkah laku dan berupaya membawa kesan kebaikan. Justeru, komunikasi tradisi dalam kepengarangan Hikayat Pelanduk Jenaka berupaya memperlihatkan tanggungjawab pengarang sebagai pembawa pesan kepada khalayak pembaca. Bukan itu sahaja, penyaluran mesej yang membawa manfaat secara tidak langsung dikaitkan dengan prinsip komunikasi daripada sudut Islam. Justeru, isi mesej yang besifat benar dan berlandaskan nilai-nilai agama Islam tersebut berupaya mengubah kehidupan manusia menjadi lebih baik. Firman Allah SWT dalam surah al-Imran, ayat 104 yang bermaksud: "Hendaklah ada di antara kamu umat yang menyeru kepada kebaikan, menyuruh dengan ma'ruf (yang baik-baik) dan melarang dari yang mungkar; dan mereka itulah yang menang".

Sesungguhnya, mesej berunsur kebenaran dan pelajaran memerlukan lima peringkat proses pemahaman dalam kalangan khalayak pembaca, iaitu penerimaan simbol, perbandingan, pengakuan, pentafsiran dan pemahaman. Pembaca atau penerima yang terdiri daripada lapang rujuk dan budaya yang sama (budaya Melayu dan beragama Islam khususnya) berupaya menghasilkan makna simbol dan pemahaman secara bersama untuk menentukan kejayaan proses komunikasi tersebut. Akhirnya, khalayak pembaca berupaya mentafsir dan memahami tanggungjawab manusia terhadap Tuhan, dirinya, masyarakat, makhluk Tuhan dan alam. Menurut Roslina (2013b, 88), insan yang seimbang daripada segi intelek, rohani, emosi dan jasmani ialah mereka yang percaya dan patuh kepada Tuhan. Tuntutan tersebut diperkukuhkan dengan firman Allah SWT dalam surah an-Nahl, ayat 90 yang bermaksud: "Sesungguhnya Allah menyuruh melakukan keadilan dan berbuat kebajikan serta memberi karib kerabat, dan melarang berbuat yang keji dan yang mungkar dan kezaliman. Dia mengajarkan kepadamu, mudah-mudahan kamu mendapat peringatan".

Pengarang Hikayat Pelanduk Jenaka berusaha menyalurkan mesej yang sarat dengan unsur kebenaran untuk ditafsir oleh khalayak pembaca dan membawa makna kebaikan. Sebagai contoh, suruhan Allah SWT kepada umat-Nya agar melakukan keadilan, berbuat kebajikan dan meninggalkan yang mungkar turut dititipkan oleh pengarang Hikayat Pelanduk Jenaka menerusi mesej yang disalurkan kepada khalayak pembaca. Hal ini serupa dengan elemen model RL: KDHT yang menekankan isi mesej yang bersifat benar. Menurut Roslina (2013b, 193), keberkesanan proses komunikasi dua hala tercapai apabila mesej yang disalurkan dapat memandu diri peserta komunikasi ke arah kehidupan yang lebih baik. Sebagai contoh, peranan SAdR yang bertanggungjawab sebagai ketua seisi rimba dan lautan turut digambarkan menerusi perwatakannya yang bertanggungjawab sebagai seorang pemimpin. SAdR menyelesaikan pelbagai masalah penghuni rimba dengan menggunakan kebijaksanaan akalnya: 
Seraya katanya Syeikh Alam di Rimba, "baiklah, akulah kelak membunuh buaya itu. Janganlah saudara hamba sekelian susah hati akan buaya itu..." (Cod. Or. 1932, 97)

Petikan tersebut memperlihatkan usaha dan tanggungjawab watak SAdR untuk memastikan keharmonian penghuni rimba. SAdR telah berjanji kepada seisi rimba dan lautan bahawa beliau akan menghapuskan raja buaya yang menggugat keharmonian seisi rimba. Setelah bermusyawarah, SAdR dan segala binatang telah bersama-sama berusaha menewaskan raja buaya. Walaupun raja buaya tidak dihapuskan oleh SAdR, namun akhirnya raja buaya dan pengikutnya telah tewas, insaf dan taat kepada SAdR sebagai ketua segala binatang di rimba dan lautan. Peristiwa tersebut memperjelaskan kepentingan tanggungjawab sebagai pemimpin, kepentingan bermusyawarah dan bantu-membantu sebagai asas keharmonian berlandaskan ajaran Islam. Hal ini membuktikan bahawa pengarang Hikayat Pelanduk Jenaka berusaha menyalurkan mesej yang sarat dengan unsur kebenaran ke arah keberkesanan proses komunikasi tradisi yang dilaksanakan.

Merujuk kepada proses komunikasi tradisi dalam kepengarangan Hikayat Pelanduk Jenaka, pengarang menjalani proses enkod, iaitu proses menghasilkan simbol-simbol untuk disalurkan lalu membawa makna dan kesan kepada khalayak pembaca. Berdasarkan model RL: KDHT, setelah penerima memperoleh mesej yang disalurkan oleh sumber, penerima akan mendekod simbol-simbol kepada makna yang difahami. Kesannya, khalayak pembaca khususnya Muslim serta bukan Muslim amnya akan memperoleh kebaikan menerusi adab komunikasi serta unsur pelajaran yang disuguhkan oleh pengarang sebagai panduan dalam kehidupan. ${ }^{2}$ Fenomena tersebut diperlihatkan menerusi kepengarangan Hikayat Pelanduk Jenaka seperti dalam petikan berikut:

"...janganlah tuan-tuan sekelian gaduh-gaduh". Maka sembah sekelian isi rimba itu, "baiklah tuanku, telah haraplah patik-patik sekelian akan kata tuanku itu dengan berkat doa tuanku yang mustajab serta dengan berkat kuat wali Allah yang karamah..." (Cod. Or. 1932, 97-98)

Petikan tersebut memperlihatkan idea pengarang menerusi mesej yang bersifat benar. Mesej tersebut berupaya memandu khalayak penerima agar jangan berseteru dan mengamalkan hidup bermuafakat dalam kehidupan nyata. Mesej yang bersifat benar tersebut sebagaimana ajaran yang terdapat di dalam al-Quran dan merujuk kepada firman Allah SWT dalam surah al-Maidah, ayat 2 yang bermaksud: "Bertolong-tolonglah kamu berbuat kebaikan dan taqwa dan janganlah kamu bertolong-tolongan berbuat dosa dan aniaya dan takutlah kepada Allah. Sesungguhnya Allah sangat keras siksaan-Nya". 
Sementara itu, komunikasi tradisi dalam kepengarangan Hikayat Pelanduk Jenaka turut membangkitkan rasa cinta dan kasih kepada-Nya. Hal ini demikian kerana secara intraperibadi, setiap umat Islam diperintahkan oleh-Nya agar sentiasa memohon hidayah daripada-Nya. Justeru, harapan, doa dan hidayah yang dipohon oleh pengarang kepada Allah SWT berupaya meningkatkan aspek kerohanian seseorang Muslim terhadap-Nya:

\footnotetext{
Wabihinastaiibillahialli, ini Hikayat Pelanduk Jenaka yang mengkhabar dirinya akan menjadi Shah Alam di Rimba. ... Hatta peristiwa pada suatu hari ia duduk berfikir dalam hatinya, "Dan jikalau demikian baiklah aku berbuat pura-pura bertapa. Maka aku katakan diriku beroleh kuat daripada wali Allah. Disuruhnya aku amalkan doa yang mustajab". (Cod. Or. 1932, 2)
}

Petikan tersebut menggambarkan situasi pengarang yang bergantung kepada keagungan Tuhan sebagai pemberi tenaga kreatif. Hubungan pengarang dengan Tuhan menerusi kepengarangan Hikayat Pelanduk Jenaka turut digambarkan menerusi perbuatan memohon taufik dan hidayah daripada Tuhan Azzawajalla di awal permulaan penulisan naskhah. Perbuatan tersebut menggambarkan harapan pengarang agar proses komunikasi tradisi yang dilaksanakan berkesan dan mencapai matlamat. Kenyataan tersebut sebagaimana elemen model RL: KDHT yang mementingkan prinsip komunikasi berpandukan al-Quran dan as-Sunnah di samping proses komunikasi pada tahap intraperibadi seperti menghubungkan diri dengan Tuhan, berdoa, memohon kekuatan jiwa dan rohani. Fenomena tersebut diperlihatkan menerusi kata-kata pembukaan dengan lafaz "Wabihinastaiibillahialli", iaitu melafazkan nama Allah SWT dengan harapan sesuatu kebaikan akan diperoleh daripada tulisan yang dihasilkannya. Sebagai khalifah di muka bumi, pengarang melaksanakan tanggungjawabnya memandu pembaca ke arah kebaikan, menggunakan akal fikiran dengan sebaiknya serta menimbang dan meyakini kewujudan Tuhan. Secara implisit, pengarang turut mengingatkan khalayak pembaca akan kepentingan berdoa dan memohon hidayah daripada-Nya.

Di samping itu, hubungan pengarang dengan Tuhan yang diperlihatkan menerusi komunikasi tradisi dalam kepengarangan Hikayat Pelanduk Jenaka turut berupaya memperkaya pengetahuan khalayak pembaca agar mendalami peranan sosial dan interaksinya dengan persekitaran. Mesej yang membawa kepada sesuatu makna menjalani proses enkod, iaitu penghasilan simbol-simbol dan pengeluaran maklumat oleh pengirim kepada penerima. Kemudiannya, penerima mengalami proses mendekod, iaitu proses memecahkan simbol-simbol kepada makna yang difahami. 
Akhirnya, Hikayat Pelanduk Jenaka berupaya mendidik, melahirkan generasi pemikir yang cenderung melakukan kebaikan serta membantu pembentukan insan yang seimbang daripada segi intelek, rohani, emosi dan jasmani. Sebagai contoh, penyaluran mesej yang mempunyai makna akan keindahan alam berupaya menjana kognitif khalayak pembaca, menghargai flora dan fauna serta bersyukur dengan ciptaan-Nya:

Maka tersebutlah pula perkataan badak, kerbau dan seladang, rusa, kijang, beruk, siamang, ungka hendak mengambil ikan dalam sungai Tasnim namanya itu. Adapun sungai itu pasirnya terlalu putih dan terlalu segala baik rupanya dan ikan pun terlalu sekali banyak. (Cod. Or. 1932, 124)

Petikan tersebut menggambarkan keindahan pelbagai perwatakan binatang di rimba dan lautan. Unsur alam yang amat indah kejadiannya berupaya memantapkan kerohanian, membantu perkembangan jiwa dan meningkatkan rasa takjub akan keajaiban ciptaan Tuhan. Kenyataan tersebut sebagaimana menurut Roslina (2013b, 260), alam merupakan hasil ciptaan Tuhan yang perlu dihargai dan dimanfaatkan oleh setiap manusia. Pada akhirnya, pengarang dan hubungannya dengan Tuhan berupaya membawa panduan, pelajaran, sumber pengetahuan dan sejarah ketamadunan Melayu dalam kalangan khalayak pembaca. Kenyataan tersebut sebagaimana menurut Azhar (2014, 100), "sastera adalah produk kebudayaan yang paling simbolik, dengan menjelma dalam pelbagai peranan sebagai wadah pengajuan metafora, didaktisme, mungkin juga penyuntik spritualisme dan pendandan estetika".

\section{Pengarang dan Hubungannya dengan Individu}

Menurut Roslina (2013b, 89), elemen hubungan antara sumber dengan individu turut dibina menerusi model RL: KDHT untuk melengkapkan proses komunikasi dua hala. Penyampaian cerita rakyat Melayu oleh sumber kepada penerima berupaya berfungsi sebagai hiburan, medium pendidikan, pembentuk etika mulia serta membentuk dan memelihara pandangan dunia dan budaya Melayu. Justeru, elemen hubungan antara penglipur lara dengan individu dihubungkan menerusi model RL: KDHT kerana komunikasi melibatkan dimensi kandungan dan hubungan. Kenyataan tersebut bersesuaian dengan pendapat Muhammad Haji Salleh $(1997,188)$ yang menyatakan, "sebagai pengarang dahulu kala, mereka berada di sumber cerita, yang seperti tasik misalnya, daripadanya dapat diambil yang terbersih dan terbaik. Generasi setelah itu tidak mengenal atau pernah menemui tasik ini, yang mereka dapat adalah air sungai sebagai warisan". 
Kenyataan tersebut membuktikan kehebatan pengarang tradisional dalam tugas kepengarangan mereka. Dalam konteks ini, proses kepengarangan menghasilkan mesej yang bermanfaat kepada peserta komunikasi serta menitikberatkan dimensi kandungan dan hubungan. Hal ini serupa dengan proses komunikasi model RL: KDHT yang turut mementingkan dimensi kandungan dan hubungan. Merujuk pendapat Hashim Fauzy (2001, 19-20), aspek kandungan merupakan tindak balas tingkah laku yang diharapkan dan aspek hubungan pula menerangkan bagaimana komunikasi itu berlaku.

Bersangkutan dengan hal tersebut, setelah melakukan proses enkod, pengarang atau sumber menyalurkan mesej yang mempunyai isi atau maklumat kepada khalayak pembaca. Menerusi hubungan antara peribadi (hubungan pengarang dengan individu), penerima berupaya memperoleh ilmu dan kebaikan setelah mendekod, memecahkan simbol-simbol lalu mentafsir makna yang disalurkan oleh sumber menerusi Hikayat Pelanduk Jenaka. Justeru, menerusi mesej yang bermanfaat, komunikasi tradisi dalam kepengarangan Hikayat Pelanduk Jenaka berupaya melahirkan individu yang berakhlak mulia dan berilmu. Menurut Roslina (2013b, 225), menerusi komunikasi dua hala terancang, sumber dapat menyisipkan nilai yang berupaya mempengaruhi perlakuan dan tindakan individu. Bersangkutan dengan kepentingan unsur nilai dan etika tersebut, Shaharuddin $(1994,21)$ turut menyatakan bahawa kebaikan dan kemuliaan individu itu seharusnya berdasarkan ukuran akhlak yang objektif dan mutlak: "Kemuliaan manikam itu daripada cahayanya". Dalam hal ini, kepentingan isi mesej yang mempunyai unsur nilai serta etika menerusi Hikayat Pelanduk Jenaka turut berfungsi sebagai wahana mendidik dan membawa teladan kepada khalayak pembaca:

Maka Syeikh Alam di Rimba pun bertitah kepada raja buayah itu, "Tuan hamba dengarlah barang kata aku ini. Janganlah engkau lalui lagi dan jangan sekali engkau berbuat aniaya akan segala isi rimba itu. Jikalau engkau lagi berbuat akan aniaya, nescaya matilah engkau oleh doa yang mustajab daripada wali Allah guru aku itu". Maka sembah raja buayah itu, "Ya Tuanku Syeikh Alam di Rimba, ada pun hamba ini tiadalah mahu melalui titah tuanku itu. Jikalau hambamu melalui seperti yang dititahkan itu, beroleh patik mati di tempuh oleh tebing seperti mati dimakan oleh ikan ... sampai kepada anak cucu patik tidaklah sekalikali beroleh selamat". (Cod. Or. 1932, 112)

Petikan tersebut jelas memperlihatkan penyaluran mesej oleh pengarang kepada khalayak pembaca dalam proses komunikasi tradisi kepengarangan Hikayat Pelanduk Jenaka. Pengarang menyampaikan isi komunikasi berbentuk nasihat secara tepat dan jelas sebagai manfaat, amalan dan panduan kepada setiap individu 
atau penerima dalam kehidupan nyata. Sebagai contoh, SAdR telah meminta raja buaya agar menyesali perbuatannya dan jangan berbuat aniaya lagi. Akhirnya, raja buaya dan rakyatnya telah kembali sembuh lalu berjanji seandainya mereka melakukan perbuatan aniaya, dirinya akan mati ditempuh tebing, mati dimakan oleh ikan malah keturunan mereka juga tidak akan dilindungi dan tidak selamat.

\section{Pengarang dan Hubungannya dengan Masyarakat}

Model RL: KDHT berupaya menjelaskan hubungan antara pengarang dengan masyarakat. Komunikasi tradisi dalam kepengarangan Hikayat Pelanduk Jenaka menghasilkan mesej yang berfungsi sebagai kawalan sosial, terkandung nilai-nilai murni yang wajar diteladani dan diaplikasikan dalam kehidupan nyata. Proses komunikasi tersebut menggambarkan tahap individu dengan kumpulan yang turut berfungsi sebagai kawalan sosial ke arah mengekalkan dan memelihara keutuhan budaya serta menerapkan aspek nilai dan etika dalam komunikasi sosial.

Sementara itu, sosialisasi merupakan salah satu fungsi komunikasi. Isi atau maklumat yang disalurkan menerusi mesej yang dienkodkan oleh pengarang Hikayat Pelanduk Jenaka turut berkaitan dengan norma dan peraturan berperlakuan seperti semangat kerjasama, perasaan kekitaan, saling hormat-menghormati, tolong-menolong dan pelbagai nilai positif yang perlu diamalkan dalam kehidupan bermasyarakat. Justeru, kepengarangan Hikayat Pelanduk Jenaka yang turut berfungsi sebagai sosialisasi mempunyai keselarian dengan komunikasi dan fungsinya. Kenyataan tersebut menjelaskan bahawa komunikasi tradisi dalam kepengarangan Hikayat Pelanduk Jenaka berupaya mensosialisasikan masyarakat dan menyediakan sumber ilmu pengetahuan. Hal ini secara tidak langsung akan memungkinkan khalayak bertindak sebagai anggota masyarakat yang sedar akan fungsi sosialnya dalam kalangan masyarakat. Oleh itu, aspek hubungan dan kandungan yang berkesan menerusi komunikasi tradisi dalam kepengarangan Hikayat Pelanduk Jenaka berupaya menghasilkan kesan perubahan tingkah laku khalayak pembaca, iaitu daripada tingkah laku negatif kepada tingkah laku positif atau mengekalkan tingkah laku yang sempurna:

Pada suatu hari maka Syeikh Alam di Rimba pun bertitah kepada segala isi rimba itu demikian bunyinya, "Hai tuan-tuan janganlah hamba sekelian aniaya dan janganlah khianat dan dengki dan jangan berbuat fitnah dan kerana di dalam firasat aku itu ada juga kedatangan bala dan huru hara juga adanya. Dan lagi jikalau ada barang suatu hal ehwal tuan-tuan sekelian maka hendaklah tuan sekelian memberi tahu kepada hamba". (Cod. Or. 1932, 121-123) 
Petikan tersebut menggambarkan nasihat dan pesanan SAdR sebagai ketua kepada seisi alam di rimba dan lautan. Menerusi watak SAdR yang dipersonifikasikan, pengarang Hikayat Pelanduk Jenaka berpesan secara eksplisit agar jangan berbuat aniaya, jangan khianat dan dengki serta jangan menabur fitnah untuk menjanjikan kehidupan yang harmoni dan sejahtera. Pesanan serta nasihat yang disampaikan oleh pengarang secara tidak langsung membawa matlamat mendidik khalayak agar tahu akan norma berperlakuan di samping menjauhi sikap aniaya, khianat, dengki dan berbuat fitnah. Mereka yang melanggar peraturan sosial tentunya akan memperoleh kesan buruk seperti bala dan bencana. Situasi tersebut menggambarkan proses belajar berperilaku yang dapat diterima secara sosial, belajar akan peranan sosial dan mengembangkan sikap sosial. Menurut Roslina (2013b, 90), model RL: KDHT memperlihatkan hubungan sumber dengan masyarakat menerusi proses komunikasi yang berupaya bertindak sebagai unsur komunikasi sosial dan kawalan sosial. Aspek nilai dalam komunikasi sosial masyarakat Melayu menekankan persoalan kesedaran terhadap nilai dan etika dalam kehidupan bermasyarakat. Kenyataan tersebut selari dengan pendapat Ding Choo Ming (2009, 154), "karya sentiasa bersifat didaktif, sebagai pedoman dan cermin untuk khalayaknya untuk berbuat baik bagi mengekalkan keharmonian masyarakatnya".

\section{Pengarang dan Hubungannya dengan Alam}

Menurut Roslina (2013b, 90), model RL: KDHT memperlihatkan hubungan antara sumber dengan alam yang berupaya berfungsi sebagai fantasi, kerohanian dan kognitif. Pemaparan ini menggambarkan manusia menyesuaikan dirinya dengan alam sekeliling dengan tujuan memenuhi keperluan asasinya. Justeru, keindahan alam tidak hanya tersimpan di alam minda pengarang malah menjadi inspirasi kepada penghasilan mesej yang ingin disalurkan kepada penerima. Pandangan dunia atau fenomena alam merupakan bahan yang diolah dan dibentuk oleh sumber atau pengarang untuk menghasilkan mesej. Mesej tersebut kemudiannya didekod oleh penerima atau khalayak pembaca kepada makna tertentu. Menerusi komunikasi tradisi dalam kepengarangan Hikayat Pelanduk Jenaka, khalayak pembaca yang berada dalam era modenisasi akan melestarikan warisan masa lalu atau menjadikannya sebagai pelajaran dalam kehidupan seharian. Menurut Roslina (2013b, 178), tujuan komunikasi adalah bersesuaian dengan cerita rakyat Melayu yang amat erat hubungannya dengan pandangan dunia, budaya, kepercayaan, pegangan, pemikiran, falsafah dan gambaran keseluruhan cara hidup masyarakat. Justeru, komunikasi tradisi dalam kepengarangan Hikayat Pelanduk Jenaka turut berupaya memperlihatkan pandangan dunia, alam dan keindahannya menerusi isi mesej yang disalurkan oleh pengarang kepada khalayak pembaca. Menurut Roslina (2013b, 177) lagi, pandangan dunia merupakan kesatuan kepada tradisi nilai dan 
budaya bagi sesebuah masyarakat. Pandangan dunia bagi sesebuah masyarakat dapat dikenal pasti menerusi perlakuan individu atau ahli masyarakatnya. Pandangan dunia tidak bersifat statik sebaliknya berkembang mengikut arus perubahan zaman. Hashim Awang (1994, 328-329) turut berpendapat bahawa masyarakat Melayu terutamanya pada tahap primitif memiliki kehidupan yang tersangat erat dan intim dengan alam, malah alam menjadi sebahagian daripada kehidupan mereka. Dengan memiliki corak kehidupan yang demikian, masyarakat Melayu menjadi begitu sensitif terhadap persekitaran, kejadian atau peristiwa yang berlaku di sekelilingnya. Sebagai contoh, komunikasi tradisi dalam kepengarangan Hikayat Pelanduk Jenaka jelas memperlihatkan kehidupan meriah seisi rimba yang terdiri daripada pelbagai jenis binatang di rimba dan lautan serta keindahan flora dan fauna. Gambaran kehidupan pelbagai jenis haiwan, habitat haiwan dan keindahan kejadian alam ciptaan Tuhan yang dipersonifikasikan oleh pengarang berupaya menyumbang ke arah pembentukan diri dan keseimbangan individu (penerima) daripada aspek jasmani, emosi, rohani, intelek dan sahsiah, seperti yang digambarkan dalam petikan berikut: "Adapun pohon Beraksar itu sedang berkembangan bunganya seperti payung kuning terkembang rupanya" (Cod. Or. 1932, 14). Petikan tersebut memperlihatkan keindahan 'pohon Beraksar' yang mewakili alam ciptaan Tuhan. Penyampaiannya dialegorikan seperti payung kuning yang sedang terkembang, cantik dan indah. Kenyataan tersebut memperlihatkan keindahan alam yang turut berupaya membawa kesan ketenangan, penawar kedukaan, menjana kognitif, menghargai keindahan alam ciptaan Tuhan, dan secara tidak langsung memantapkan kerohanian serta ketakwaan terhadap kebesaran Ilahi. Fenomena tersebut turut diperlihatkan dalam petikan berikut:

Maka tersebutlah pula perkataan badak, kerbau dan seladang, rusa, kijang, beruk, siamang, ungka hendak mengambil ikan dalam sungai Tasnim namanya itu. Adapun sungai itu pasirnya terlalu putih dan terlalu segala baik rupanya dan ikan pun terlalu sekali banyak. (Cod. Or. 1932, 124)

Petikan tersebut menggambarkan jalinan erat antara alam dengan komunikasi tradisi dalam kepengarangan Hikayat Pelanduk Jenaka. Penghasilan mesej menerusi Hikayat Pelanduk Jenaka memaparkan keindahan alam sebagai tanda kesempurnaan alam ciptaan Tuhan dan menuntut setiap individu agar menghargainya. Kenyataan tersebut sinonim dengan pendapat UU Hamidy (1994, 190) yang menyatakan bahawa cara berfikir yang metaforik dalam tradisi Melayu sebati dengan cara-cara agama Islam menyampaikan sebahagian ajarannya dengan menggunakan lambang-lambang alam. Luahan rasa melalui penggunaan imej dan alam memberikan kesan emosi estetik kepada khalayak. 
Justeru, gambaran keindahan pelbagai perwatakan binatang di rimba serta lautan dan unsur alam yang amat indah kejadiannya berupaya memantapkan kerohanian, membantu perkembangan jiwa dan meningkatkan rasa takjub akan keajaiban ciptaan Tuhan. Alam tidak wujud tanpa penciptanya dan Allah SWT adalah penciptanya, mengatur segala kejadian alam dan melindunginya. Alam dan kejadiannya oleh Allah SWT terdiri daripada tiga kelompok kejadian, iaitu di langit, di bumi dan yang berada di antaranya. Firman Allah SWT dalam surah Taha, ayat 6 yang bermaksud: "Kepunyaan-Nya apa-apa yang di langit, apa-apa yang di bumi, apa-apa yang di antara keduanya dan apa-apa yang di bawah tanah". Oleh itu, fungsi mesej berunsur alam dalam kepengarangan Hikayat Pelanduk Jenaka adalah bertepatan dengan kenyataan Roslina (2013b, 89) yang menyatakan bahawa penyampaian mesej oleh sumber berfungsi sebagai hiburan, medium pendidikan, pembentuk etika mulia serta membentuk, memelihara pandangan dunia dan budaya Melayu.

\section{Kesimpulan}

Kepengarangan Hikayat Pelanduk Jenaka berupaya menghasilkan matlamat dan kejayaan komunikasi tradisi sekiranya pengarang dan khalayak mempunyai daya pemikiran yang berupaya mentafsir dan memahami simbol, berupaya menjalani proses enkod dan dekod serta menilai sesuatu persoalan yang disuguhkan dengan menggunakan akalnya. Secara total, komunikasi tradisi dalam kepengarangan Hikayat Pelanduk Jenaka jelas memperlihatkan aspek hubungan dan kandungan di samping membawa kebaikan dan manfaat dalam kalangan pembaca. Hal ini berkemungkinan pengarang Hikayat Pelanduk Jenaka mempunyai kemahiran serta kreativiti mengarang, mempunyai taraf pengetahuan menulis dan daya sikap ingin membentuk khalayak pembaca ke arah kebenaran. Kelebihan bakat mengarang yang dipunyainya turut dibantu oleh pekerjaannya sebagai seorang jurutulis yang berkemahiran, mempunyai kepakaran dan pengalaman mengarang yang memantapkan kepengarangannya. Sehubungan itu, pengaplikasian model RL: KDHT dalam merungkai kepengarangan Hikayat Pelanduk Jenaka berupaya memperlihatkan proses komunikasi yang merangkumi aspek hubungan dan kandungan.

Di samping mesej yang menghiburkan, komunikasi tradisi dalam kepengarangan Hikayat Pelanduk Jenaka turut berupaya memperlihatkan keunikan nilai Melayu untuk dijadikan pelajaran, panduan dan amalan dalam kalangan pembaca. Kesannya, kepengarangan Hikayat Pelanduk Jenaka berupaya menghibur dan mendidik audien, melestarikan serta memperluaskan horizon budaya Melayu. Justeru, komunikasi tradisi dalam kepengarangan Hikayat Pelanduk Jenaka berupaya membentuk keseimbangan dan kesempurnaan emosi, rohani dan 
intelek khalayak pembaca. Kerelevanan model RL: KDHT dan kepengarangan Hikayat Pelanduk Jenaka dibuktikan menerusi kesepadanan, saling hubung antara elemen komunikasi, sastera dan budaya. Unsur-unsur komunikasi yang bersifat sistematik dan terancang serta penggabungjalinan hubungan pengarang dengan Tuhan, individu, masyarakat dan alam menerusi model RL: KDHT berupaya melengkapkan proses dan peranan komunikasi tradisi dalam kepengarangan Hikayat Pelanduk Jenaka.

\section{Penghargaan}

Makalah ini merupakan sebahagian daripada kajian penyelidikan penulis menerusi program pasca kedoktoran (affiliated fellow) mengenai Interaksi Sosial dalam Manuskrip Melayu di International Institute for Asian Studies (IIAS), Leiden University dari November 2014 hingga November 2016. Penulis ingin mengucapkan setinggi-tinggi penghargaan kepada Universiti Putra Malaysia dan Kementerian Pendidikan Malaysia atas pembiayaan program pasca kedoktoran ini. Penulis juga ingin mengucapkan penghargaan kepada Dr. Aone Van Engelenhoven; Dr. Philippe Peycam, Pengarah IIAS; dan Dr. Willem Vogelsang, Pengurus IIAS, Leiden University, Leiden, Belanda.

\section{Nota}

1. Hubungan sumber dengan Tuhan menerusi model RL: KDHT bukan sahaja mencakupi elemen intrapersonal dan adab berkomunikasi, malah ia juga menitikberatkan perbuatan memandu penerima (menerusi mesej yang disalurkan) berdasarkan pelajaran yang terkandung di dalam al-Quran dan hadis (Roslina 2013b, 88). Justeru, analisis mengenai hubungan sumber dengan Tuhan turut merujuk kepada terjemahan firman Allah SWT menerusi al-Quran sebagai hujah sokongan untuk membuktikan bahawa mesej yang disalurkan oleh pengarang Hikayat Pelanduk Jenaka bersifat benar dan berlandaskan pelajaran yang terdapat di dalam al-Quran.

2. Adab berkomunikasi berdasarkan perintah-perintah yang terdapat di dalam al-Quran dan hadis turut dinyatakan oleh Roslina (2013b, 88). Menerusi al-Quran, keindahan dan sifat-sifat murni Rasulullah SAW dapat dihayati, terutama daripada segi akhlak, adab berkomunikasi dan pengajaran baginda yang menjadi ikutan dalam kehidupan.

\section{Bibliografi}

Abdul Hakim. n.d. Cod. Or. 1932, Hikayat pelanduk jenaka. Special collection, Leiden University Library, Leiden, The Netherlands.

Abdul Syukur Ibrahim and Lilik Wahyuni. 2010. Interaksi sosial dalam ekspresi bahasa jender kajian harmoni sosial dalam perspektif Hermeneutika. Laporan Penelitian Tahap II Hibah Penelitian Strategis Nasional, November. 
Abu Hassan Sham. 1997. Langkah-langkah memasyarakatkan manuskrip Melayu. In Tradisi Penulisan Manuskrip Melayu, ed. n.a., 265-272. Kuala Lumpur: Perpustakaan Negara Malaysia.

Alex Sobur. 2003. Semiotika komunikasi. Bandung: Penerbit Pt Remaja Rosdakarya.

Azhar Ibrahim. 2014. Cendekiawan Melayu penyuluh emansipasi. Selangor: Strategic Information and Research Development Centre.

Ding Choo Ming. 1997. Skiptoria Melayu: Tinjauan umum. In Tradisi Penulisan Manuskrip Melayu, ed. n.a., 217-226. Kuala Lumpur: Perpustakaan Negara Malaysia. . 2003. Kajian manuskrip Melayu: Masalah, kritikan dan cadangan. Kuala Lumpur: Utusan Publications \& Distributors Sdn. Bhd.

2009. Kearifan lokal dalam naskhah Nusantara di pinggir abad ke-19. In Kearifan lokal yang terkandung dalam manuskrip lama, eds. Ding Choo Ming, Henri Chambert-Loir and Titik Pudjiastuti, 143-167. Bangi: Institut Alam dan Tamadun Melayu (ATMA).

E.P. Wieringa. 1998. Catalogue of Malay and Minangkabau manuscripts in the Library of Leiden University and other collections in the Netherlands in volume one comprising the acquisitions of Malay manuscripts in Leiden University Library up to the year 1869. Leiden: Legatum Warnerianum, Leiden University Library. 2007. Catalogue of Malay and Minangkabau manuscripts in the Library of Leiden University and other collections in the Netherlands in volume two comprising The H.N. Van Der Tuuk Bequest by the Leiden University Library in 1896. Leiden: Legatum Warnerianum, Leiden University Library.

Gardner, H. 1983. Frames of minds: The theory of multiple intelligences. Oxford: Clarendon Press.

Goriaeva, L. 2001. La dernière hikayat Malaise. Archipel 61: 99-113.

H Mahmud Yunus. 1979. Tafsir Quran Karim. Singapore: Basheer Ahamed.

Haron Daud. 2004. Manuskrip ilmu pendukunan dunia Melayu: Metode kajian dan cadangan pengembangan ilmu itu di institusi pengajian tinggi. Paper presented at the International Conference Scholarship in Malay World Studies: Looking Back, Striding Ahead, organised by the International Institute for Asia Studies (IIAS), Leiden University and Dewan Bahasa dan Pustaka Malaysia (DBP), Leiden, The Netherlands, 26-28 August 2004.

Harun Mat Piah. 1994. Hikayat Syamsul Anwar dan Raja Aisyah Sulaiman: Karya dan pengarang dalam tradisi kesusasteraan Melayu klasik. In Pengarang, teks dan khalayak, ed. Sahlan Mohd. Saman, 252-272. Kuala Lumpur: Dewan Bahasa dan Pustaka.

Hashim Awang. 1994. Pengkajian sastera: Pengkaedahan Melayu. In Pengarang, teks dan khalayak, ed. Sahlan Mohd. Saman, 326-335. Kuala Lumpur: Dewan Bahasa dan Pustaka.

Hashim Fauzy Yaacob. 2001. Komunikasi antara manusia. Johor Bahru: Penerbit Universiti Teknologi Malaysia.

Khairuddin Mohamad, Ghazali Ismail, Wan Zalina Wan Othman and Ratna Laila Shahidin. 2014. Kebudayaan Melayu. Selangor: Penerbitan Multimedia Sdn. Bhd.

Liaw, Yock Fang. 1975. Sejarah kesusasteraan Melayu klasik. Singapore: Pustaka Nasional. 
Mana Sikana. 2013. Dari barat ke timur: Teori dan kritikan sastera. Kuala Lumpur: Dewan Bahasa dan Pustaka.

Mansor Ahmad Saman, Ramli Mohamed and Shawaluddin Anis. 1984. Pengantar komunikasi. Pulau Pinang: Penerbit Universiti Sains Malaysia.

Mohd. Yusuf bin Arshad. 1961. Pantun. Kuala Lumpur: Dewan Bahasa dan Pustaka.

Muhammad Haji Salleh. 1997. Memperbaharui pengarang. In Tradisi penulisan manuskrip Melayu, ed. n.a., 183-210. Kuala Lumpur: Perpustakaan Negara Malaysia.

Mustafa Mohd. Isa. 1984. Penglipur lara Melayu. Petaling Jaya: Penerbit Fajar Bakti Sdn. Bhd.

Nurhayati Diyana Musa. 2015. Konflik-konflik dalam drama Shaharom Husain. Master's diss., Universiti Putra Malaysia, Selangor.

Roslina Abu Bakar. 2011. Cerita rakyat Melayu: Analisis dari aspek komunikasi dua hala. $\mathrm{PhD}$ diss., Universiti Malaya, Kuala Lumpur.

2012. Model R.Lina: Komunikasi dua hala terancang dalam tradisi lisan. Jurnal Peradaban Melayu 7: 185-208.

. 2013a. Model R.Lina: Komunikasi dua hala terancang (KDHT) dalam penyampaian crita rakyat Melayu. TENIAT: International Journal of Creative Future and Heritage 1(1): 176-194.

2013b. Komunikasi dua hala terancang: Satu aplikasi dalam penyampaian cerita rakyat Melayu. Bangi: Penerbit Universiti Kebangsaan Malaysia.

Sahlan Mohd. Saman, ed. 1994. Pengarang, teks dan khalayak. Kuala Lumpur: Dewan Bahasa dan Pustaka.

Shaharuddin Maaruf. 1994. Nilai dan gaya pemikiran dalam sastera. In Pengarang, teks dan khalayak, ed. Sahlan Mohd. Saman, 16-28. Kuala Lumpur: Dewan Bahasa dan Pustaka.

Shahnon Ahmad. 1994. Proses kreatif: Kesegalaannya berpusatkan insan. In Pengarang, teks dan khalayak, ed. Sahlan Mohd. Saman, 1-15. Kuala Lumpur: Dewan Bahasa dan Pustaka.

Shamsudin Abdul Rahim. 1993. Komunikasi asas. Kuala Lumpur: Dewan Bahasa dan Pustaka.

Siti Hawa Salleh. 1987. Masalah pengeditan manuskrip Melayu. Dewan Sastera Ogos: 41-46.

1997. Hikayat Gul Bakawali: Perkembangan, bentuk dan zaman. In Pengarang, teks dan khalayak, ed. Sahlan Mohd. Saman, 203-224. Kuala Lumpur: Dewan Bahasa dan Pustaka.

Teuku Iskandar. 1989. Historiografi Melayu. Paper presented at Persidangan Antarabangsa Pengajian Melayu, organised by Jabatan Pengajian Melayu, Universiti Malaya, 21-23 August 1989.

UU Hamidy. 1994. Teks, pengarang dan masyarakat dalam sastera Melayu di Riau. In Pengarang, teks dan khalayak, ed. Sahlan Mohd. Saman, 168-195. Kuala Lumpur: Dewan Bahasa dan Pustaka. 